\title{
Antiviral properties of the seed extract of an Indian medicinal plant, Pongamia pinnata, Linn., against herpes simplex viruses: in-vitro studies on Vero cells
}

\author{
M. ELANCHEZHIYAN, S. RAJARAJAN*, P. RAJENDRAN, S. SUBRAMANIAN and \\ S. P. THYAGARAJAN $\dagger$
}

Department of Microbiology, Dr A. L.M. Post Graduate Institute of Basic Medical Sciences, Taramani, Madras-600 113 and * Department of Botany, Presidency College, Madras-600 005, India

\begin{abstract}
Summary. Pongamia pinnata, Linn., an Indian medicinal plant used in the Ayurvedha and Siddha traditional medicine systems, for treatment of clinical lesions of skin and genitalia, was evaluated for antiviral properties against herpes simplex virus type-1 (HSV-1) and type2 (HSV-2) by iri-vitro studies in Vero cells. A crude aqueous seed extract of $P$. pinnata completely inhibited the growth of HSV-1 and HSV-2 at concentrations of 1 and $20 \mathrm{mg} / \mathrm{ml}$ $(w / v)$, respectively, as shown by complete absence of cytopathic effect.
\end{abstract}

\section{Introduction}

Acute and recurrent herpes simplex virus (HSV) infections are worldwide in distribution and several antiviral compounds have been introduced into therapeutic use during the past two decades. ${ }^{1,2}$ Their conflicting efficacy in recurrent infection and in immunodeficient patients ${ }^{2,3}$ as well as the problem of prohibitive costs in developing countries, has necessitated the search for alternative drugs. Two traditional Indian medicine systems, Ayurvedha and Siddha, mention the usefulness of the Indian medicinal plant Pongamia pinnata, in clinical lesions of skin and genitalia. ${ }^{4,5}$ However, the validity of its medicinal properties has not been evaluated scientifically. In this pilot study, the antiviral effect of an extract of $P$. pinnata seeds against herpes simplex virus type-1 (HSV-1) and type-2 (HSV-2) was evaluated in Vero cells.

\section{Materials and methods}

\section{Cell culture}

Vero cells obtained from the National Facility for Animal Tissue and Cell Culture, Department of Biotechnology, University of Poona Campus, Pune, India, were grown in Eagle's Minimum Essential Medium (EMEM) containing Earle's salts, L-glutamine, non-essential amino acids, sodium bicarbonate, goat serum (heat inactivated at $56^{\circ} \mathrm{C}$ for $30 \mathrm{~min}$ ) $5 \%$

Received 2 Jan. 1992; revised version accepted 10 Sept. 1992. † Correspondence should be sent to Dr S. P. Thyagarajan. and antibiotics (penicillin $100 \mathrm{IU} / \mathrm{ml}$ and streptomycin $100 \mu \mathrm{g} / \mathrm{ml}$ ). The maintenance minimum essential medium (MMEM) was prepared similarly with goat serum $2 \%$. The cells were cultivated according to the standard procedure of Grist et al. ${ }^{6}$

\section{Virus strains and inhibition assays}

HSV-1 (AC strain) and HSV-2 (HV-219 strain) were propagated in Vero cells and used at a concentration of $10^{6} \mathrm{pfu} / \mathrm{ml}$ in the experiments. The sensitivity of HSV strains to $P$. pinnata seed extract was tested by quantitative CPE reduction assays ${ }^{7}$ and the percentage inhibition of the virus growth was calculated according to the formula of Wachsman and Coto. ${ }^{8}$

\section{Preparation of aqueous $P$. pinnata seed extract}

$P$. pinnata is a terrestrial tree belonging to the family Papillionaceae. Because Ayurvedha and Siddha literatures stress the use of the seeds, they were used in this study. Seeds were collected from dried fruits, surfacesterilised in ethyl alcohol $70 \%$ and powdered after weighing. Aqueous extracts $(1 \mathrm{~g} / \mathrm{ml})$ were prepared in sterile double-distilled water. This was filtered through a sterile gauze cloth and then through a seitz filter. The concentration of the filtered extract was calculated by comparing the weight difference between similar quantities of plain double-distilled water and plant extract. No preservative was used and the sterility of the preparations was checked by standard procedures. The sterile extract was distributed in small volumes and stored at $-20^{\circ} \mathrm{C}$ until required. 


\section{In-vitro antiviral studies of $P$. pinnata seed extract}

Qualitative analysis. Two groups of six tubes containing Vero cell cultures were inoculated with HSV-1 $\left(10^{6} \mathrm{pfu}\right)$. Seed extract $(0 \cdot 1 \mathrm{ml}$ of $1 \mathrm{mg} / \mathrm{ml} \mathrm{w} / \mathrm{v}$ extract $)$ was added to one of the groups. Control groups were inoculated with phosphate buffered saline (PBS). MMEM ( $2 \mathrm{ml})$ was added to each culture after incubation for $90 \mathrm{~min}$ at room temperature. The tubes were then incubated at $37^{\circ} \mathrm{C}$ for 2 weeks. They were observed with a Nikon inverted microscope each day for evidence of cytopathic effect (CPE). Similar experiments were done for HSV-2.

\section{Dose-response analysis}

Dose response was estimated by a CPE reduction assay on Vero cell monolayers and the percentage virus inhibition was calculated according to the formula described by Wachsman and Coto. ${ }^{8}$

\section{Virus inhibition $(\%)=$}

Number of plaques in the tubes inoculated

100 with virus + plant extract

Number of plaques in the tubes $\times 100$ inoculated with virus alone

For HSV-1, 36 tubes containing Vero cell cultures were used in six groups: A, B, C, D (test groups), E (positive virus control) and F (PBS control). In groups A, B, C and D, different concentrations of the seed extract were used. A similar experiment was done for HSV-2, in which 43 Vero cell cultures were used in seven groups: A, B, C, D, E (test groups), F (virus positive control) and $\mathrm{G}$ (PBS control).

The dose-response pattern was assessed from the percentage inhibition of CPE at each concentration of the extract at $24,48,72,96,120,144$ and $168 \mathrm{~h}$. Statistical evaluation was by Student's $t$ test.

\section{Results}

\section{Qualitative analysis}

Qualitative analysis of HSV-1 gave the following results. The virus control showed extensive CPE after incubation for $72 \mathrm{~h}$, whereas the group treated with seed extract showed no CPE even after a week. The uninfected cells in the extract control tubes were unaffected. The seed extract completely inhibited the multiplication of $\mathrm{HSV}-1$ at a concentration of $1 \mathrm{mg} / \mathrm{ml}$ w/v. Qualitative analysis of HSV-2 showed that an extract concentration of $1 \mathrm{mg} / \mathrm{ml} \mathrm{w} / \mathrm{v}$ could not bring about complete inhibition and only a concentration of $20 \mathrm{mg} / \mathrm{ml}$ completely inhibited replication by HSV-2.

\section{Dose-response analysis}

Table I shows the dose-response pattern of HSV-1 to $P$. pinnata seed extract, confirming the ability of a concentration of $1 \mathrm{mg} / \mathrm{ml}$ to completely inhibit growth of HSV-1; the lower concentrations were less effective. The mean percentage inhibition of each concentration of the extract was statistically significant. However, the tubes with lower concentrations of the extract

Table I. Dose-response pattern of HSV-1 to $P$. pinnata

\begin{tabular}{|c|c|c|c|c|c|c|c|}
\hline \multirow{2}{*}{$\begin{array}{l}\text { Concentration of } \\
\text { extract }(\mathrm{mg} / \mathrm{ml})\end{array}$} & \multicolumn{7}{|c|}{ Mean percentage inhibition (SD)* at } \\
\hline & $24 \mathrm{~h}$ & $48 \mathrm{~h}$ & $72 \mathrm{~h}$ & $96 \mathrm{~h}$ & $120 \mathrm{~h}$ & $144 \mathrm{~h}$ & $168 \mathrm{~h}$ \\
\hline $0 \cdot 25^{\mathrm{a}}$ & $62 \cdot 5(1 \cdot 7)$ & $4 \cdot 3(0 \cdot 4)$ & 0 & & & & \\
\hline $0 \cdot 50^{\mathrm{b}}$ & $85 \cdot 6(1 \cdot 5)$ & $70 \cdot 3(1 \cdot 5)$ & $15 \cdot 0(3 \cdot 2)$ & 0 & & & \\
\hline $0.75^{\mathrm{c}}$ & $98.5(0 \cdot 5)$ & $86 \cdot 0(1 \cdot 6)$ & $73 \cdot 0(1 \cdot 2)$ & $18 \cdot 0(1 \cdot 6)$ & 0 & & \\
\hline $1 \cdot 0^{\mathrm{d}}$ & $100(0)$ & $100(0)$ & $100 \quad(0)$ & $100(0)$ & $100(0)$ & $100(0)$ & $100(0)$ \\
\hline
\end{tabular}

All values were statistically significant at $24 \mathrm{~h}$ : a versus $\mathrm{b}, \mathrm{p}<0.05 ;$ a versus $\mathrm{c}$ and $\mathrm{c}$ versus $\mathrm{d}, \mathrm{p}<0.001$.

* Expressed as a percentage of the input virus dose $\left(10^{6} \mathrm{pfu}\right)$.

Table II. Dose-response pattern of HSV-2 to P. pinnata

\begin{tabular}{|c|c|c|c|c|c|c|c|}
\hline \multirow{2}{*}{$\begin{array}{l}\text { Concentration of } \\
\text { extract }(\mathrm{mg} / \mathrm{ml})\end{array}$} & \multicolumn{7}{|c|}{ Mean percentage inhibition $(\mathrm{SD})^{*}$ at } \\
\hline & $24 \mathrm{~h}$ & $48 \mathrm{~h}$ & $72 \mathrm{~h}$ & $96 \mathrm{~h}$ & $120 \mathrm{~h}$ & $144 \mathrm{~h}$ & $168 \mathrm{~h}$ \\
\hline $1^{\mathrm{a}}$ & $61 \cdot 3(0 \cdot 8)$ & $3 \cdot 3(0 \cdot 8)$ & 0 & & & & \\
\hline $5^{b}$ & $73.8(1.5)$ & $63 \cdot 3(1 \cdot 5)$ & $4 \cdot 8(3.9)$ & 0 & & & \\
\hline $10^{\mathrm{c}}$ & $83 \cdot 5(1 \cdot 1)$ & $73.3(0.8)$ & $62 \cdot 8(1 \cdot 5)$ & $10 \cdot 3(3 \cdot 6)$ & 0 & & \\
\hline $15^{\mathrm{d}}$ & $98 \cdot 3(0 \cdot 4)$ & $83 \cdot 5(1 \cdot 1)$ & $75 \cdot 5(0.5)$ & $66 \cdot 3(1 \cdot 3)$ & $16 \cdot 5(1 \cdot 1)$ & 0 & \\
\hline 20 & $100(0)$ & $100(0)$ & $100(0)$ & $100 \quad(0)$ & $100 \quad(0)$ & $100(0)$ & $100(0)$ \\
\hline
\end{tabular}

Statistical comparisons: a versus b at 24 h not significant but at 48 h statistically significant $(\mathrm{p}<0 \cdot 05)$; b versus c and c versus $d$ at $24 \mathrm{~h}$ highly significant $(\mathrm{p}<0.001)$.

* Expressed as a percentage of the input virus dose $\left(10^{6} \mathrm{pfu}\right)$. 
showed viral proliferation (appearance of CPE) on further incubation. In addition, the dose-response study of HSV-2 (table II), revealed that an extract concentration of $20 \mathrm{mg} / \mathrm{ml}$ was required to bring about $100 \%$ inhibition of viral growth. The mean percentage inhibition at each concentration of the extract was statistically significant. As with HSV-1, growth of HSV-2 was observed after further incubation of the tubes with the lower concentrations of the extract.

\section{Discussion}

Viral inhibition studies with the extract of $P$. pinnata seeds against HSV-1 and HSV-2 were evaluated in vitro. The most striking observation was the total inhibition of growth of HSV-1 and HIV-2 at concentrations of $1 \mathrm{mg} / \mathrm{ml}$ and $20 \mathrm{mg} / \mathrm{ml} \mathrm{w} / \mathrm{v}$ respectively, whereas even at the highest concentrations the extract was not toxic for Vero cells. Acute and chronic toxicological studies conducted in Swiss albino rats showed the safety of the $P$. pinnata seed extract (unpublished observations). When these observations are compared with those of Fiala et al., ${ }^{9}$ the higher

\section{References}

1. Palmieri G, Ambrosi G, Ferraro G, Agrati AM, Palazzini E. Clinical and immunological evaluation of oral ribavirin administration in recurrent Herpes simplex infections. $J$ Int Med Res 1987; 15: 264-275.

2. Meyers JD, Wade JC, Mitchell CD et al. Multicenter collaborative trial of intravenous acyclovir for treatment of mucocutaneous Herpes simplex virus infection in the immunocompromised host. Am J Med 1982; 73: 229-235.

3. Gnann JW, Barton NH, Whitley RJ. Acyclovir: mechanism of action, pharmakokinetics, safety and clinical applications. Pharmacotherapy 1983; 3: 275-283.

4. Kirtikar KR, Basu BD (eds) Indian medicinal plants. India, M/s Bishen Singh Mahindrapal Singh. 1975: 830-832.
MIC required for $P$. pinnata seed extract against HSV1 and HSV-2 may be due to the crude nature of the extract. The difference in MIC $P$. pinnata extract for HSV- 1 and HSV-2 is similar to their observation with adenine arabinoside, cytosine arabinoside and idoxyuridine. Purification of the active principle(s) isolated from $P$. pinnata might resolve its real anti-HSV potential. Even though the above observations could be considered as most encouraging, it must be remembered that they are preliminary, and further chemical characterisation of the active principle(s) and reanalysis of their antiviral properties must be undertaken.

This work was conducted with financial assistance from the Indian Council of Medical Research, IRIS No. 3/1/1/9 (8601550)/86-NCD- III. We thank Dr Pradeep Seth, Department of Microbiology, AIIMS, New Delhi, for providing the HSV-1 and HSV-2 type strains; and the National Facility for animal tissue and cell culture, Department of Biotechnology, Pune, for supplying the Vero cell line. We gratefully acknowledge the assistance of $\mathrm{Dr}$ Manjamuthu, Department of Statistics, Madras Medical College, Madras; Dr Sumathy Vasudevan, King Institute of Preventive Medicine, Madras; Drs V. Jayakumar, Kumanan, Albert and Daniel, Madras Veterinary College, Madras; and the technical assistance of Mrs C. Geetha, Department of Microbiology, Dr A. L.M. PGIBMS.

5. Nadkarni KM (ed). Indian materia medica. India, Bombay Popular Prakashan. 1986: 1001-1004.

6. Grist NR, Bell EJ, Follette EAC, Urquhart GED (eds). Diagnostic methods in clinical virology, 3rd edn. Oxford, Blackwell Scientific Publications. 1979: 60-79.

7. Laren C, Corey L, Dekket C, Barry DW. In vitro sensitivity to acylovir in genital Herpes simplex viruses from acyclovirtreated patients. $J$ Infect Dis $1983 ; 148: 868-875$.

8. Wachsman MB, Coto A. Search for antiviral activity in higher plant extracts. Fitoterapia 1988; LIX: 422-424.

9. Fiala M, Chow AW, Miyasaki K, Guze LB. Susceptibility of Herpesviruses to three nucleoside analogues and their combinations and enhancement of the antiviral effect at acid pH. J Infect Dis 1974; 129: 82-85. 